\title{
Interface Between Family Farming and School Feeding: barriers and coping mechanisms from the perspective of different social actors in Southern Brazil ${ }^{1}$
}

\author{
Márcia Pozzagnol Mossmann², Carla Rosane Paz Arruda Teo ${ }^{3}$, \\ Maria Assunta Busato ${ }^{4}$ and Rozane Marcia Triches ${ }^{5}$
}

\begin{abstract}
Family farming came to school as a public policy in Brazil, linked to National School Feeding Program (PNAE - Programa Nacional de Alimentação Escolar, in Portuguese). In order to discuss the interface between family farming and school feeding, regarding barriers and coping mechanisms, 35 social actors were interviewed in Santa Catarina, Southern Brazil. The barriers were cost of goods, bureaucracy, insufficient technical assistance, resistance to changes, weaknesses in the organization of farmers and public managers. The conclusion is that studied interface has being built in facing those obstacles with dialogue mechanisms, intersectionality, investment, training activities and organization.
\end{abstract}

Key-words: Local development, rural development, nutrition programs and policies.

Resumo: A agricultura familiar chegou à escola como uma política pública no Brasil, ligada ao Programa Nacional de Alimentação Escolar (PNAE). Para discutir a interface entre a agricultura familiar e a alimentação escolar, com relação a barreiras e mecanismos de enfrentamento, 35 atores sociais foram entrevistados em Santa Catarina, no Sul do Brasil. As barreiras identificadas foram custo, burocracia, assistência técnica insuficiente, resistência às mudanças, fragilidades na organização dos agricultores e gestores públicos. Conclui-se que a interface

1. Data de submissão: 20 de setembro de 2016. Data de aceite: 19 de março de 2017.

2. Universidade Comunitária da Região de Chapecó. Chapecó, Santa Catarina, Brasil. E-mail: marciapozzagnol@unochapeco.edu.br

3. Universidade Comunitária da Região de Chapecó. Chapecó, Santa Catarina, Brasil. E-mail: carlateo@unochapeco.edu.br

4. Universidade Comunitária da Região de Chapecó. Chapecó, Santa Catarina, Brasil. E-mail: assunta@unochapeco.edu.br

5. Universidade Federal da Fronteira Sul. Realeza, Paraná, Brasil. E-mail: rozane.triches@gmail.com 
estudada tem sido construída no enfrentamento desses obstáculos por meio de mecanismos de diálogo, intersetorialidade, investimento, atividades de capacitação e organização.

Palavras-chaves: Desenvolvimento local, desenvolvimento rural, programas e políticas de nutrição e alimentação.

\section{Introduction}

Family farming has been recognized as strategic for achievements in the field of sovereignty and food and nutrition security, as well as for the protection of agricultural biodiversity and sustainable use of natural resources, for the appreciation of traditional foods and the preservation of cultural diversity, also representing an opportunity to boost local economies (FAO, 2014). In Brazil, family farming came to the school as a public policy, linked to the National School Feeding Program (PNAE - Programa Nacional de Alimentação Escolar in Portuguese), in 2009. The PNAE is the oldest social program of the Brazilian federal government in the area of food and nutrition, considered an axis of public policies in that field.

The program, originated in the 1940s and legally introduced in 1955 (BRASIL, 1955), is recognized as one of the largest in the world in the area of school feeding, serving universally approximately 43 million students of basic education in the country (FNDE, 2013). Since its inception until the present, the legislation that supports the implementation of the Program is consolidating and making more explicit the intention to constitute PNAE as local development mechanism. Between 1955 and 1993, the Program management focused on the federal level and foods were purchased through bidding processes, and were predominantly formulated and processed (TRICHES \& SCHNEIDER, 2010). Since 1994, the program management has been decentralized, becoming the responsibility of the Education Departments of the cities. That new model allowed improving the nourishment supplied to the school, causing a reduction in the supply of formulated, pre-cooked and dehydrated foods, which predominated in menus (DOMENE, 2008; SPINELLI \& CANESQUI, 2002).

In 2009, the legislation governing the program was updated with the Federal Law No. 11,947, which established new guidelines for school meals in Brazil, linking family farming to PNAE. From that law, according to Article 14, at least, $30 \%$ of funds transferred by the Federal Government to cities through the National Fund for Education Development (FNDE Fundo Nacional do Desenvolvimento da Educação, in Portuguese) must be used for the purchase of healthy food produced by local family farmers. In this case, preference should be given to organic foods as well as those produced by indigenous communities, maroon and agrarian reform settlements. This innovative question stood out on the acquisition of food for school feeding, expressing support for sustainable local development by strengthening small farmers. The law brings another significant innovation for the PNAE as, from it, the conventional bidding process is exempted for the purchase of family 
farming products, since the prices are consistent with those on the local market and that food meets the requirements of quality control established by existing health conditions (BRASIL, 2009).

Indeed, this public procurement model originates from the Food Acquisition Program (PAA - Programa de Aquisição de Alimentos, in Portuguese), established in 2003 by Federal Law n. 10,696 (BRASIL, 2003). The program supports direct purchases from local small farmers by the government for the construction of food stocks (and price regulation) and for use in public food programs, thus strengthening family farming and, at the same time, improving the food and nutrition security status of vulnerable groups (ROCHA, 2009). It is noteworthy that, since the beginning of the PAA, it was observed that a significant part of the products acquired through the program was destined to the PNAE at the state and municipal levels.

Therefore, with its new legal framework, PNAE inaugurates - on a larger scale - a new model of public procurement in Brazil, through public call edicts, whose simplification improves access for small producers to a relevant institutional market, contributing to the local development and for facing the rural exodus. In practice, nowadays, that means that the equivalent of 310 million dollars are applied each year in family farming in the country, in order to promote local sustainable development, to value healthy eating cultural traditions and to improve food and nutrition security levels. That joint has reflected in the presence of food locally produced by family farming in the school environment, through its inclusion in the PNAE menus, creating an important institutional market and generating income for family farmers (SCOTT et al., 2013). Furthermore, the Federal Law n. 11,947 also makes the inclusion of less processed food in school stronger, respecting regional habits and encouraging a healthier consumption.

The changes in the law have extended the possibility of production and commercialization of family farmers and favored the students' access to the fresh food consumption. Consequently, the supply of processed foods in school decreased (SARAIVA et al., 2013). The obligation to purchase food from family farming emerged as a way for protecting producers' income, besides it facilitates the commercialization due to simplification of conventional legal procedures (VILLA REAL \& SCHNEIDER, 2011). That means the law promoted qualitative progress in the PNAE and triggered a new stage in its implementation.

From that perspective, PNAE becomes a public policy of structural nature, contributing to local development, to the strengthening of vulnerable groups (farmers and students of basic education) and the reordering of the food system, with the potential to deflect positively to a broader population level (TRICHES, GERHARDT \& SCHNEIDER, 2014). Nevertheless, although the institutional purchases currently represent one of the most significant incentive policies of family farming, it is important to monitor its implementation process in order to identify possible adjustments necessary to ensure its effectiveness. In the specific case of PNAE, several studies have been conducted in Brazil and have pointed out some obstacles faced by farmers and managers in the process of giving materiality to the Federal Law n. 11,947/2009.

The problems reported by those studies relate mainly to regularity of production, logistics, quantity, quality and diversity of produced food, attendance of health issues, bureaucracy, planning and segment organization weaknesses (BACCARIN et al., 2011; BAVARESCO \& MAURO, 2012; SOUZA, 2012; SMITH et al., 2013; BEVILAQUA \& TRICHES, 2014). Notably, logistics appears as one of the biggest obstacles, especially involving issues related to transport and distribution of products for a large number of delivery points, which may represent a significant barrier for small producers for its costs (BACCARIN et al., 2012; BAVARESCO \& MAURO, 2012; CHAIM \& BELIK, 2012).

In addition, the demand for high quantity of products in larger cities located in metropolitan areas exceeds the service capacity of the contingent of local farmers, which is exacerbated 
by a context of lack of technical assistance to producers (OLIVEIRA, SOUSA \& SILVA, 2013; SMITH et al., 2013). Some authors have also reported a lack of interest of farmers regarding the inclusion in the school food market (SARAIVA et al., 2013), problems in the preparation of public call notices (BACCARIN et al., 2012; SARAIVA et al., 2013; BEVILAQUA \& TRICHES, 2014) and conflicts between managers and farmers (SILVA et al., 2013).

In the process of implementation of Federal Law n. 11.947/2009, as obstacles appear to the involved social actors, alternatives to face and overcome them are also configured, in the dynamics of building an interface between family farmers and school feeding. Among the coping mechanisms, researchers have particularly pointed to inter-agency coordination (TRICHES \& SCHNEIDER, 2010; CHAIM \& BELIK, 2012; SOUSA et al., 2013; BEVILAQUA \& TRICHES, 2014), partnerships between public administration and research institutes, besides encouraging the formalization and organization of farmers in cooperatives and associations, and strengthening technical assistance teams (BELIK \& CHAIM, 2009; SOUZA, 2012; TRICHES \& SCHNEIDER, 2012; BEZERRA et al., 2013; SOUSA et al., 2013; SILVA, DIAS \& JUNIOR, 2015).

However, due to the relatively recent enactment of Federal Law n. 11,947/2009, there are few studies in the state of Santa Catarina, Southern Brazil, on the family farm interface with school feeding. It is noteworthy that Santa Catarina is the Brazilian state that presents one of the highest percentages of family farmers in the country ( $87 \%$ of farms), which account for $64 \%$ of total gross value of the sector's production in the state, although they hold only $44 \%$ of its total area. Those data demonstrate the persistence of inequality in rural Santa Catarina (MATTEI, 2010), despite its agriculture being the most dynamic and diverse in the country and having production base rooted in family farming (ZOLDAN, 2010).

Reinforcing the importance and potential of family farming in Santa Catarina, $82 \%$ of the economically active people in the agricultural establishments of the state work in family farming (IBGE, 2006). However, there are also inequalities in that aspect, as only $41 \%$ of people employed in family farms are women and that the sector is in full aging process, with very low insertion of young people in the sector, to the detriment of its renewal (MATTEI, 2010). It is relevant, in short, to point out that the Santa Catarina rural sector is facing some challenges, such as population displacement, especially young people, to urban centers, due to the sector's inability to maintain the occupation of all family members (MARCONDES, 2010).

In that context, the access to institutional markets, promoted by intersectoral public policies, is an alternative to boost the sector, contributing, at the same time, to improve the living and health conditions of the general population. Given that scenario, we present this article. The aim is to discuss how the interface between family farming and school feeding has being built in cities of Santa Catarina state, Brazil, in terms of the factors that represent obstacles to its consolidation and also on those that are mechanisms for addressing and overcoming those limitations, from the perspective of different social actors involved in the process.

\section{Theoretical basis}

According to the above, we emphasize that the theoretical background of this study is centered in the vulnerability issue, with an interdisciplinary perspective, which merges concepts from the sociology and health fields.

Based on this assumption, vulnerability is defined as the degree to which individuals and households are susceptible or incapable of dealing with adverse events (physical, social, emotional, economic, environmental etc.). Vulnerability is a multidimensional construct, not easily captured with a single variable. One can say it is an expression of people's sensitivity to the risks and their ability to respond and recover from the impacts of hazards (NUNES, 2016). 
In that context, from the sociology field emerge the livelihoods approach, according to which the most vulnerable persons/households are those that are both highly prone to adverse external events and lacking in the assets or social support systems that could carry them through periods of adversity (ELLIS, 2000). The term livelihoods attempts to capture not just what people do in order to make a living, but the resources that provide them with the capability to build a satisfactory living, the risk factors that they must consider in managing their resources, and the institutional and policy context that either helps or hinders them in their pursuit of a viable or improving living. That approach is based, at least, in three concepts: assets, activities and outcomes. The assets (or capitals) are the resources owned or accessed and managed by people in the living process. That resources are often categorized in some different types: human capital (skills, education, health), physical capital (produced investment goods), financial capital (money, savings, loan access), natural capital (land, water, trees etc.), and social capital (networks and associations). The activities, in the livelihoods framework, are the things people do in pursuit of a living. Finally, the risk factors that surround making a living are summarized as the vulnerability context, and the structures associated with government, authority, laws and rights, democracy and participation are summarized as the policy and institutional context. People's livelihoods efforts, conducted within these contexts, result in outcomes: higher or lower welfare, reduced or raised vulnerability to adverse events, improving or degrading environmental resources and so on. That process potentially enable virtuous spirals of asset accumulation that can provide people with exit routes from adversities (ELLIS, 2000, 2003a, 2003b; ELLIS et al., 2008).

So-called livelihoods approaches work with people, supporting them to build upon their own strengths and realize their potential, while at the same time acknowledging the effects of policies and institutions, external shocks (whether natural or man-made), internal stress and trends. This provides the basis for identifying the constraints to livelihoods development. Such constraints can lie at local level or in the broader economic and policy environment. They may relate to a specific sector or they may be more to do with social conditions, health, education or infrastructure. Thus, the livelihoods approach sets out to be people-centered and holistic, and to provide an integrated view of how people make a living within evolving social, institutional, political, economic and environmental contexts (CARNEY, 1999).

Since the health field, the vulnerability framework focuses on three components from individual and collective levels. The first component is the individual dimension of vulnerability, which assumes that people are susceptible to adversities, to a greater or lesser extent, in terms of characteristics, knowledge, attitudes, perceptions and personal capacities that make them more exposed to challenges or better prepared to face them. In the second component, the social dimension of vulnerability is considered, and the focus is on cultural, moral, political, economic, and institutional factors that may determine the means of exposure to challenges/adversities. The third component is the programmatic dimension, which focuses on how policies, programs and services can interfere with people's ability to respond to challenges/ adversities (AYRES et al., 2006).

One should consider that people faced with a situation of vulnerability could react in two ways: facing or adapting, depending on the available conditions (context and resources). Coping mechanisms refer to the methods people use to overcome an adverse situation in a context of vulnerability, aiming to overcome it. They are strategies built to respond to crises and may become momentary alternatives. Therefore, coping mechanisms aim to moderate or reduce the negative impacts of situations that cause vulnerability, or to promote positive effects to avoid greater impacts. On the other hand, adaptation strategies involve people's 
ability for making livelihoods to evolve in order to accommodate adversity, expanding the range of variability with which they can cope with situations of vulnerability. Thus, adaptation strategies represent more stable alternatives, as they anticipate possible crises, ensuring greater stability when situations of vulnerability occur. Successful adaptations, therefore, mean that people are less prone to crises over time, improving their ability to withstand adversity and becoming better prepared to deal with them (ELLIS, 2000). The response capability of individuals and communities, through the development of coping mechanisms and adaptation strategies, depends directly on the set of resources they have (ELLIS, 2003).

Considering the presented elements, this study proposed to construct an interdisciplinary perspective from the notion of vulnerability, combining approaches from the fields of sociology and health. We argue that this theoretical option is adequate to the study developed, allowing the apprehension of how social actors construct coping mechanisms and adaptation strategies in relation to situations that affect their livelihoods and represent, to some extent, moments of crisis. Thus, knowing the coping mechanisms adopted at these moments is a fundamental step to promote adaptations that contribute to less vulnerable contexts.

\section{Background}

Currently, there is a trend to favor the local purchase of food for school feeding programs. In particular, there is a movement towards so-called homegrown school feeding, with the emphasis on food procured in the communities around the school, thus enhancing both the rural economy and food quality (ALDERMANN \& BUNDY, 2011).

Providing healthy school meals integrated with nutritional education and health measures can produce better school performance, nutritional literacy as well as employment and income in adult life. The procurement of food for school meals from local farming communities supports family farmers and livelihoods, and promotes sustainable local markets for diverse, nutritious foods. Combined interventions can also unleash a chain of beneficial impacts (GLOBAL PANEL, 2015). That means to promote accumulation of resources that can guarantee better living conditions for the populations in medium and long term.

Somecountrieshavemadesignificant progress in this area, encouraging agriculture-educationnutrition synergies as part of a creative legislative agenda. In the United States, the Agricultural Act passed in 2014 included provisions to improve meals in schools by increasing the use of local and regionally produced foods, coupled with learning activities such as school gardening, farm visits, culinary classes, and the integration of nutritionrelated education into curricula. In India, since 2001, a legislation has required the government to provide meals in all primary schools, many of them are procuring local produce. Besides, efforts have been made to improve school infrastructure for the program, and to overcome the difficulties related to access to drinking water, which remain as challenges to be addressed, as well as the quality and stability of the program at the national level under a decentralized system (GLOBAL PANEL, 2015).

In 2009, the government of Kenya also launched a homegrown school feeding program. A targeting exercise identified 28 marginal agricultural districts with access to markets for the new program. The cash is transferred directly to schools for local purchase of cereals, pulses, and oil. Ghana and Nigeria have rolled out pilot homegrown school feeding programs in 2003, designed to link school feeding to agricultural development through the purchase and use of locally produced food. These programs are now being evaluated, but it is important to consider that local procurement can be increased progressively as the program evolves and mechanisms are put in place to guarantee the stability of the process (BUNDY et al., 2009). 
In order to present the current state of school feeding and the possibilities of its links with local purchases from family farming in Latin America, national studies were developed in Bolivia, Colombia, El Salvador, Guatemala, Honduras, Nicaragua, Paraguay and Peru. The results of these studies showed that in all countries there is a significant number of family farmers with some level of organization and a significant capacity to produce food. However, there were observed weaknesses of development and investment in terms of food safety, price control and agricultural insurance, which are elements that should be considered in public policies when planning a homegrown school feeding, in order to remove the barriers that limit family farmers to participate in public procurement processes (FAO, 2013).

At present, institutional purchases are one of the most significant public policies for family agriculture. Particularly in Brazil, the Law n. $11,947 / 2009$ is widely recognized as an opportunity for linking community and family farming, as well as for rescuing food legacy, reconnecting the dimensions of food production and consumption (TRICHES \& SCHNEIDER, 2010). The food purchase from family farming becomes important in that it simultaneously meets the students' nutritional needs and ensures economic and social development of the farmers, based on alternative production and marketing methods for their products. These alternative methods include the formation of short chains, establishing links between producers and consumers in order to consolidate the social bond and meet the demand of public institutions, increasing the variety of products offered, providing consumption of safety food in the school environment, thus ensuring food and nutrition security (BRASIL, 2016). From the perspective of vulnerability, this context promotes livelihoods diversification for family farmers as well as access to healthy food and formation of better eating habits for the school community.

However, one should consider that farmers face difficulties in providing food for PNAE, particularly as regards the production regularity, logistics, quantity and quality of food produced, food safety issues, bureaucracy and lack of planning. Logistics appears as one of the greatest difficulties for family farmers because just a few municipalities are able to provide transportation for goods or pay for it. Similarly, farmers usually do not have financial structure to outsource this service or to purchase a suitable vehicle (BAVARESCO \& MAURO, 2012).

Souza (2012) conducted a study in three regions of São Paulo state on the food supply from family farming for PNAE. According to the author, the difficulties faced by family farmers were related to their suitability to legislation, small range of products (because the farmer tends to concentrate production in some foods whose sale is more likely), organization of logistics operations (mainly involving the delivery system and product packaging), and management activities, due to their little experience with PNAE.

A research carried out in Espera Feliz city, Minas Gerais state, by Silva, Dias and Junior (2015) on organizational changes in enterprises of family farmers reported that the failure to meet the health requirements regarding processing, storage and transport of goods was the main difficulty faced.

Thus, it is important to note that the operational difficulties have represented a significant challenge for purchasing family farming products to PNAE. The costs of packaging and logistics, besides membership costs to associations and cooperatives, can lead many farmers to give up participating in PNAE, even those who have production capacity to meet demands (TRICHES \& BACCARIN, 2016).

As obstacles arise in the Law implementation process, alternatives to address them are also built. The study carried out by Smith et al. (2015), in Santa Catarina state, about the potential and difficulties for supplying school meals through purchasing family farming food, points out that dialogue between various social actors as well as the partnership between Department of Education 
and cooperatives were mechanisms developed to overcome difficulties. Intersectoral action was also the alternative found in the municipality of São Bernardo do Campo, São Paulo state, to promote the participation of family farming in PNAE, as shown by Chaim and Belik (2012).

Souza (2012) also reported the organization, in a study developed in São Paulo state. The author stated the organization of farmers in cooperatives enabled the commercialization of products for a broader area, including a larger number of municipalities. The technical guidance and training activities were coping mechanisms to overcome difficulties related to sanitary requirements in Minas Gerais state (SILVA, DIAS \& JUNIOR, 2015).

We argue that currently, eight years since the approval of the Law, many of the mentioned difficulties still persist, and others probably have emerged in this period, which requires propose, develop and consolidate strategies that provide the overcoming.

The study develops such issues, in order to contribute for promoting advances in the implementation process of the Law and to consolidate the interface between family farming and school feeding.

\section{Methodology}

One conducted a descriptive exploratory study, of qualitative approach, involving key actors in building the interface between family farming and school feeding promoted by Federal Law n. 11,947/2009.

The study was conducted in 2014 in eight cities in the state of Santa Catarina. The state has a population of 6,248,436 inhabitants, comprising 295 municipalities (IBGE, 2011). Among all cities, there are $234(79.32 \%)$ small-sized 1 cities (with less than 20,000 inhabitants), 34 (11.53\%) are small-sized 2 (with population between 20,001 and 50,000 inhabitants), 15 (5.08\%) are mediumsized (with population between 50,001 and 100,000 inhabitants) and $12(4.07 \%)$ are large- sized (with populations between 100,001 and 900,000 inhabitants). There are no cities in the state classified as metropolis (more than 900,000 inhabitants) (IBGE, 2002).

For this study, the selection of the cities occurred in two stages. Initially, there was the identification of all cities that publicized public call notices for acquisition of food from family farms for school feeding in Santa Catarina between 2012 and 2013, which totaled 96 cities (32.5\%). The final sample consisted of eight cities, selected for qualitative research with the actors involved in the phenomenon under study. For the second stage of selection, the criteria were the diversity of the population size and the proportion of funds invested in the purchase of family farming products, and acceptance to participate in the survey. Table 1 presents the socio-demographic characterization of the selected cities and, in order to preserve their anonymity they were identified by letters (A, B, C, D, E, F, G, H).

The group of the research subjects consisted of 35 social actors involved in the studied interface in the eight selected cities. The participants' identification was according to the category to which they belong: managers (8 technical managers, nutritionists responsible for PNAE); farmers ( 9 family farmers); consumers (10 members of the School Feeding Council/CAE, teachers, principals and school cooks); members of the Technical Assistance and Rural Extension/ ATER (8 technicians and rural extensionists). The inclusion criteria were the acceptance of the subject to participate in the research and the involvement with the studied phenomenon in one of the selected cities.

In order to collect data, a semi-structured interview technique was used, applying specific guides for each category of social actor. The interviews were scheduled, performed individually and in time and place chosen by the participants. For data analysis, one adopted the technique of thematic content analysis (MINAYO, 2013), from two previous categories: barriers and coping mechanisms in the construction of the family farming interface with school feeding. 
Table 1. Sociodemographic data of the cities selected for the study, Santa Catarina state, 2014

\begin{tabular}{|c|c|c|c|c|c|c|c|}
\hline City & Size & $\begin{array}{l}\text { Population } \\
\text { (thousand)* }\end{array}$ & $\begin{array}{c}\text { Demographic } \\
\text { density } \\
\left(\text { inh./ } / \mathbf{k m}^{2}\right)^{* *}\end{array}$ & $\begin{array}{c}\text { Urbanization } \\
\text { rate } \\
(\%)^{1} \\
\end{array}$ & $\mathrm{HDI}^{2}$ & $\begin{array}{l}\text { GNP per capita } \\
(\mathbf{R} \$)^{2}\end{array}$ & $\begin{array}{c}\text { Average value applied } \\
\text { in family farming } \\
(\%)^{* * *}\end{array}$ \\
\hline A & Large-sized & 183,530 & 317,87 & 92 & 0,790 & $33,411.42$ & 23,69 \\
\hline B & Smalll-sized 1 & 3,787 & 45,46 & 39 & 0,747 & $46,880.58$ & 61,42 \\
\hline C & Small-sized 1 & 10,213 & 43,62 & 59 & 0,744 & $26,031.44$ & 41,48 \\
\hline $\mathrm{D}$ & Large-sized & 515,288 & 486 & 97 & 0,809 & $40,184.13$ & 37,69 \\
\hline E & Large-sized & 156,727 & 59,60 & 98 & 0,770 & $22,767.76$ & 37,88 \\
\hline F & Small-sized 2 & 22,101 & 135,9 & 82 & 0,781 & $36,402.02$ & 22,25 \\
\hline G & Small-sized 1 & 16,332 & 142,51 & 83 & 0,783 & $47,355.11$ & 58,07 \\
\hline $\mathrm{H}$ & Small-sized 2 & 36,306 & 154,89 & 88 & 0,801 & $32,550.57$ & 46,68 \\
\hline
\end{tabular}

* According to data obtained in the 2010 Population Census (IBGE, 2011); ** Data for population density, HDI (Human Development Index) and GNP (Gross National Product) were obtained on the websites of the cities; ${ }^{* * *}$ Average percentage applied by the cities in purchasing food from family farming.

Source: Own preparation, 2016.

The Ethics Committee for Research Involving Human Subjects approved this study (Opinion n. $1,207,443)$.

\section{Results and discussion}

One develops, at this point, the discussion on barriers and coping mechanisms in the construction of family farming and school feeding interface in the surveyed cities from the perspective of different social actors interviewed. A cross-sectional analysis plan was adopted, which takes as its object the textual material produced by the group of participants. That methodology was chosen because there is no intention to deepen the reflection within the category of each involved actor in the exploited interface or from the local cut.

On the contrary, we start from the assumption that in the process of giving concreteness to politics - by its implementation - the actors have as background their personal and professional trajectories, as well as the position they occupy in the scenario study. In this way, the actors interact in a systemic logic, going from disputes to coordinated collective efforts, resulting in advances, retreats and new arrangements, which lead to other advances, retreats and rearrangements. Therefore, it is important to consider the perspective of the group of actors in a complex systemic organization, in order to produce a recognition of the phenomenon under study.

\subsection{Barriers in the construction of the family farming interface with school feeding}

The barriers most reported by the interviewed social actors were costs, insufficient technical assistance, bureaucracy, resistance and organization fragility.

Nutritionists mainly report barriers relating to costs. They are the technical managers of the program and often face difficulties to purchase products from family farms, given that they generally have a higher price than the ones provided by large wholesales by traditional bidding process, which also eventually reduces the diversity of foods that are purchased from family farming.

So, one of the difficulties is the price issue, for example, of the family farming. I pay more for them; the products of family farming are a bit more expensive than the ones I use in normal, traditional bidding. (Nutritionist - City F).

Given that the production of the family farmer is developed on small farms located in hilly regions and/or in unfavorable conditions for 
334 Interface Between Family Farming and School Feeding: barriers and coping mechanisms from the perspective of different social actors in Southern Brazil

large scale, the costs of the production process tend to be higher when compared to large producers or wholesalers, who often work with large quantities and at low cost.

The low value transferred by FNDE for municipalities to purchase food for school feeding vary from nine to thirty cents of dollar per student/day (BRAZIL, 2013). Furthermore, costs of family farming products are higher than the ones of the conventional suppliers. This context explains why the cost is one of the first difficulties placed on the agenda by the interviewed managers who experience the need to devise mechanisms to cope with it.

In this context, it is important to point out the contradictions in public procurement between efficiency, with the acquisition of cheaper food, and sustainability, which operates with the idea to ensure the best value (MORGAN \& SONNINO, 2008). Thus, the purchase of food from family farms, even resulting in higher cost compared to purchases from large suppliers, is, in medium and long terms, investment in the improvement of social, health and environment conditions (TRICHES \& CRUZ, 2016).

Several interviewees mentioned the insufficient technical assistance as an obstacle to be faced in the process of articulation between school feeding and family farming, which stands out as the lack of assistance and support to the production.

Farmers complained a lot. They called me to try to solve and I said I could not. Their relationship with EPAGRI [Agricultural Research and Rural Extension Company of Santa Catarina] was very difficult, they lacked support, technical assistance, and then, in the meetings of COMSEA, EPAGRI charged too, but did not give this support to them. (Nutritionist - City H).

The inclusion of family farmers as suppliers for school feeding involves the partnership of various sectors of public administration, especially the Municipal Department of Agriculture and the Agricultural Research and
Rural Extension Company of Santa Catarina (EPAGRI), responsible for direct aid to farmers through technical assistance provision.

Insufficient assistance was reported mainly by farmers, who are the actors most directly affected by the issue, given the importance of that service to improve the production process and, hence, the capacity to meet the demands presented by the program. Technical assistance is, therefore, dynamic element of the production process, favoring the farmers to advance, including in addressing the legal implications of becoming a school feeding supplier, which increases their chances to insert in a qualified manner in PNAE.

Some public policies have been developed in Brazil, in order to encourage family farming, as the Federal Law n. 12,188 (BRAZIL, 2010), which established the National Technical Assistance and Rural Extension Policy for Family Farming and Agrarian Reform and which has, among its objectives, the promotion of sustainable rural development and improvement of the farmers' quality of life.

Bavaresco and Mauro (2012) point out policies that provide free technical assistance to family farming with emphasis on property management - which usually appears as one of the main difficulties faced by that group - assist in its self-organization and facilitate the regular provision for PNAE. That was also one of the barriers mentioned in this study, according to the various interviewed actors in the studied cities. In this light, despite the various changes produced in the Brazilian legislation, such as the creation of specific policies and incentives to strengthen family farming, some difficulties seem to be more resistant and require alternative devices to overcome them.

However, it is important to emphasize that, during the interaction with the different interviewed stakeholders it was possible to observe the articulator role played by ATER professionals in some surveyed cities, which appears to be essential in the process of integration of farmers in institutional markets such as PNAE. 
Respondents also highlighted the bureaucracy that permeates the inclusion of family farmers in the process of providing food for school feeding from the changes proposed by the Federal Law n. 11,947/2009 as a barrier to be faced, particularly regarding the documentation required to participate in the public call notices.

We had problems with respect to documentation as well, for it is too bureaucratic, because initially the Aptitude Declaration had my mother's name, who owns the land, and had to go to my name, because she did not fit as a family farmer because she retired. (Farmer - City E).

Aptitude Declaration is one of the documents required so that the farmer can participate in the process of public bidding and preparation of the sales project for school feeding. Producers considered that declaration as a difficulty to access that market, since, to get it, it is necessary that the farmer meets a series of requirements that, until then, were not required to sell their products elsewhere, as markets and fairs.

Study by Souza (2012), in São Paulo, in Southeastern Brazil, confirms those findings, emphasizing that one of the obstacles still faced by family farmers to enter the formal market is the bureaucracy to obtain the Aptitude Declaration. Additionally, it was reported the slowness of the public agencies responsible for issuing the document which makes the farmers able to access that particular marketing space represented by PNAE.

For cities, the new requirements presented by Federal Law n. 11,947/2009 provide greater security in the relationship between public administration and the farmer, because only farmers who are committed and able to meet the demand of the program offer to participate.

From the moment the Federal Law n. $11,947 / 2009$ came into force, some demands were imposed on farmers so that they could provide their products to PNAE. Then, a process of adaptation and standardization of products offered to the program was necessary, being the resistance presented by farmers in making the necessary changes one of the difficulties faced.

Producer adequacy, having the product, having the label according to the law, having the right product, understanding what kind of product we wanted. (Nutritionist - City G).

Rural extensionists from EPAGRI and nutritionists, actors with technique training in the area of food production, highlight the adequacy constraints of farmers in relation to food production, including the standardization issues, from the packaging, labeling, to the preparation and preservation of products. They are also responsible for qualifying farmers on specifications that products must have to meet the demands of school feeding, given that children are a vulnerable public that requires special attention to their food.

However, I see this issue of legal referrals, to regulate the product, as one of the major obstacles for us to put the family farming products in school feeding. There is this mandatory issue, to have the product registered, to have a proper container, well presented, with a label that also meets it. These things, among others, end up being obstacles. (ATER - City A).

When the city is aware of the farmer mode of production, the public administration and the PNAE manager start to feel more confident in purchasing from that producer. At this point, a relationship of trust between producer and consumer may be constructed (TRICHES \& CRUZ, 2016), which favors investments from both parties to the diversification and expansion of production to meet program demands and contribute to soften the inflexibility of bureaucratic procedures against the recognition of the quality of the product.

The organizational weakness of farmers also results in limitations in implementing the program, especially regarding the quantity and diversity of produced food. 
336 Interface Between Family Farming and School Feeding: barriers and coping mechanisms from the perspective of different social actors in Southern Brazil

The difficulty in making the farmer produce, scale production, for him to have production throughout the year. Because with the farmer is like this: the cabbage harvest, they all have cabbage, and in the off-season, no one has cabbage! Therefore, organizing this schedule is a difficulty. (Farmer/President of the Cooperative - City B).

Farmers undertake to deliver a certain amount or a certain product. Then, they can't and don't give any justification, you know? You keep waiting for the food that is on the menu to be distributed that week and just does not come, is not delivered. (Consumer, Member of CAE - City E).

Those statements point to a difficulty faced mainly by nutritionists, who depend on the farmer's commitment on the sales project to ensure the provision of adequate food, and in accordance to the planning, under the program. Thus, if the farmer does not produce to meet the demands throughout the school year, the functioning of the program may be impaired, as reported by technicians and extensionists who work in the cities.

Public call notices should contain information that can minimize those difficulties, such as the types of required food, the corresponding quantities and delivery schedule, which contributes to producers to have clarity on the commitment they will assume when effecting the sales contract, favoring its planning and organization of production activities to serve it. In this sense, a well-elaborate public call notice allows the farmers to recognize the possibility of service against the self-assessment of their ability and production stability to ensure the provision according to the schedule presented by the acquirer.

However, the statements indicate that such practice is not reality in some cities, where farmers have been unable to deliver the contracted amount, and have concentrated the production of some foods they could produce throughout the year in only few months. That condition may relate to weaknesses in the preparation of the public call notice, which may not present sufficient information and specifications.

Regarding the government, organizational problems regarding the payment of farmers were also highlighted, experiencing significant delays.

We wait a lot to get paid [laughs], it's the town hall failure. I do not know how it is, but let's say it takes long, right? (Farmer - City C).

As for the town hall, a few months ago there was a little delay in payment. (Farmer - City E).

For the administration, the issue of closing well the payment, you know? Payment delays. No one stopped receiving, but delays and the staff do not have that working capital to endure. So, a month, okay, two months, it gets complicated for them. They do not have that reserve to working. (ATER - City F).

The PNAE has its decentralized management since 1994, and different levels of government share the responsibilities for the program. Thus, the federal government, through the FNDE, passes a fixed amount per student to cover the cost of their food during their stay at school, whereas the states and cities complement that value, making effective financial compensation.

In this dynamic, the FNDE passes the resource in ten installments during the school year to cities, performing deposit in a specific bank account for that purpose (BRAZIL, 2013). The management of those resources is up to the cities, providing correct payments and avoiding damage to farmers. As verbalized by the participants of this study, the timely payment is important and delays are harmful, especially for smaller producers, whose survival may be unfeasible, as they do not have working capital to enable them to withstand those conditions. Besides, late payments, especially when usual, break trustful relationships that strengthen the articulation of family farming with the school feeding.

In this sense, a study by Marques et al. (2014), on the perception of farmers about the food 
supply for PNAE, identified the late payment as one of the main barriers faced, restricting the inclusion of new farmers in the program and hindering the creation of a trustful relationship between the parties.

In summary, the family farm interface with school feeding has been facing many obstacles in the implementation of Federal Law n. 11,947/2009, with some variations resulting from the social worker directly involved in the process in the studied cities. Therefore, the following issues were considered obstacles: the cost of family farming products, the bureaucracy of enabling farmers to supply, insufficient technical assistance to meet the demands of farmers, resistance to change the ways of producing and weaknesses in the organization of farmers and public managers.

\subsection{Coping mechanisms of barriers in the construction of the family farming interface with school feeding}

The study findings highlight the factors that have been contributing to face and overcome difficulties in the implementation process of the Federal Law n. 11,947/2009, regarding the changes in family farming.

The dialogue was one of the mechanisms that emerged from the interviews, established through regular contact between the actors and through meetings.

Every year we meet the farmers and then perform an assessment. So, when we call to sign the sales contracts, we always left open for the assessment, right? We make a whole guidance and assessment. We see what people have to say, if it is good, if it is not, what needs to improve. This is done every year, because all is new: the sales project, the products, sometimes even the farmers... (Employee of the Department of Agriculture - City G).

Given the uncertainties and doubts of a new process, the involved actors highlighted dialogue as essential to overcome the obstacles to the inclusion of family farmers in school feeding.
In order to encourage dialogue, as illustrated in the presented speeches, holding meetings involving the different actors is an opportunity to dispel doubts about the public call notice, its procedures and steps, the purchase and delivery of food and payments. In this dynamic, close and trustful relationships between the parties establish and strengthen, essential to achieve the objectives of the program, including schoolchildren, farmers, the environment and community development as a whole.

Silva, Dias and Junior (2015) highlighted the dialogue as a strategy to overcome the barriers that hinder the consolidation of family farming interface with school feeding, recommending meetings among managers, agents involved in purchases in the cities and farmers and unions to discuss the preparation of public call notices and the process of products supply.

Soares et al. (2015) also pointed out that the dedication of local actors was essential to accomplish the purchase of family farming products to school feeding, reporting that the proximity between cities and farmers enabled a dialogue among the actors and allowed to overcome difficulties in implementing the program, especially those related to compliance with the quality standards.

Thus, in line with the literature, there is evidence of the recognition of dialogue as an important mechanism to face the obstacles in the implementation of PNAE in the studied cities.

Complementary and closely related to the dialogue, the intersectoral approach was highlighted as a key element to face the experienced obstacles in the implementation of PNAE with the application of Federal Law n. $11,947 / 2009$.

We had a very strong partnership with the staff of the Secretariat of Agriculture and Fisheries. The concern of the secretary of agriculture, also the involvement of the Department of Education, to work more together, to work as a whole. (Consumer, Member of CAE - City E). 
In this perspective, the speech evidences the intersectorality in implementing the program in the studied cities as a way to overcome the challenges the cities face to adapt to changes arising from the Federal Law n. 11,947/2009. The joint work between departments and public bodies is essential to the effectiveness of the program, since PNAE is a policy of an essentially intersectoral nature. Partnerships and linkages between sectors provide knowledge exchange among managers, technicians and farmers, favoring the necessary adjustments and preventing work overload in some links in the process, becoming a shared execution.

Since it is not solely a policy of health, education, agriculture or assistance, but, recognizing its relationship with all of those fields, PNAE is understood as an intersectoral policy. In this sense, the definition of Navarro (2011) stands out, which highlights the intersectorality as a public policy management model based primarily on contractual relations among various sectors, in which responsibilities, resources and goals are shared by establishing a relationship of respect for the autonomy of each sector, but also interdependence.

Thus, we consider the implementation of the Federal Law n. 11,947/2009 is still on course, and that evidences of intersectoral action as one of the coping mechanisms of the difficulties encountered in that process seem to be in a building stage and not consolidated yet in the studied cities. Therefore, we suggest that the actors involved in this movement should be alert to the traps that could compromise the progress in this field.

Another point considered essential to overcome the identified limitations was the performance of formative and qualification actions focused on the farmers, providing greater knowledge to the group regarding technical issues of seeding, harvest, production, handling and transportation of the products provided for the school feeding.

Since I came here, we have done work on good manufacturing practices; food handling...
There is a group with agribusinesses. Courses have also been made in partnership with SENAR [National Rural Learning Service], and we made an excursion to Verê, Paraná state, because they have agroecological production with organic production seal. Some farmers from here that produce were also there. (ATER - City C).

Therefore, there is a concern by the cities to offer courses and training for farmers, so that they improve their production through the adoption of new techniques from production to the marketing of their products. EPAGRI and the National Rural Learning Service (SENAR) are the main responsible for the promotion of those initiatives in the cities, and they have trained technicians to do so, qualifying family farmers to be inserted or better located in the institutional market of school feeding.

Souza (2012) identified, in a study conducted in three regions of the state of São Paulo, Brazil, a predominance of banana monoculture in the studied territory, a fact that worried both managers of PNAE as farmers due to loss of diversity production. In order to overcome that limitation, many farmers in the region have decided to participate in training programs promoted in partnership with local technicians, aiming to increase production and better serve the PNAE.

Thus, conducting courses, training, seminars and other training strategies are resources to face the obstacles that arise in building the interface under study in the studied cities, reflecting in qualification of family farmers that provide school feeding.

From the speeches of the participants, they also identified the contribution of investments to face some of the reported limitations:

The cooperative also had to adapt to be able to provide school feeding. We had to rent a shed to make the deposit, buy trucks to deliver the food. (President of the cooperative - City B).

Yes, there was enough investment: the food central was built, and so we end up getting 
all the products from the market, everything. There is one more part of surveillance, and has its own car to go pick up these foods and that, too, we did not have before. Therefore, it changed enough for us here. (Employee of Agriculture Department - City G).

The respondents' statements point out that there was need for investments from both sides government and farmers - to face the difficulties experienced in the implementation of Federal Law n. 11,947/2009. With the Law, it became imperative that farmers had to meet some rules so that they could provide school feeding, such as obtaining specific documentation, standardization of products, compliance with health standards, logistic development, among others. Similarly, the cities also needed to do their part and invest in adjustments to their structure to store and distribute food provided by family farmers.

Oliveira, Sousa and Silva (2013) pointed out that, in order to overcome the obstacles faced by the farmers' association, the city made an agreement with a company to process the products, supplied truck to make the delivery of food, provided physical structure and some employees, aiming to ensure adequate food supply.

The interviewees highlighted the organization of the farmers as key element to face the problems found in the studied cities regarding the inclusion of food from family farming in PNAE.

We are doing several meetings with local governments, to talk about it, because it needs to be explained before, right? So, there is already a favorable opinion, and the next year the public call is already in progress, right? Therefore, the year ends and the same process keeps on going in the other. (Farmer - City D).

From the speeches of the interviewed social actors, the organization of farmers emerged, either individually or in cooperatives and associations, as crucial to move forward in that process, enabling the expansion of production, improving the quality of products as well as meeting the demands of the program.

Therefore, the organization and planning of local entities, such as cooperatives and associations involved with PNAE, tend to minimize the problem of irregular food supply, in view of the greater number of producers involved and concerted action .

The institutional market of PNAE, from the Federal Law n. 11,947/2009, presented an effective and secure marketing opportunity for family farmers. In this perspective, Mosimann (2014) states territorial organizational dynamics planned by farmers, especially the formation of cooperatives and associations, empower those actors, improving their ability to plead their interests, needs and demands.

In this sense, the legal framework of PNAE encourages the organization of farmers into cooperatives or associations. Moreover, as emphasized by Marques et al. (2014), being part of a community demands team spirit, conversation, companionship and respect, and dialogue and cooperation in the group must be greater than the individualism that can compromise the relationship between the members and the access to new markets.

\section{Final thoughts}

The results of this study indicate that, during the implementation process of the Federal Law n. $11,947 / 2009$, the respondents reported various obstacles for both parties - farmers and town halls - who presented stood face of this new market. It is important to emphasize that the difficulties were different in each studied city, due to variations resulting from the social agent more directly involved in each city. However, insufficient technical assistance and problems in the organization of the processes in the city were the main difficulties pointed out by farmers. For the town halls, the cost, the resistance and weaknesses of organization of the farmers were 
mentioned as the most common limitations to be faced.

Facing this scenario, it was necessary the mobilization of mechanisms that allowed coping and overcoming the obstacles. Therefore, those are dialogue, intersectionality, investments, training activities and organization. These mechanisms have encouraged the establishment and strengthening of trustful relationships that promoted awareness of both parties about the importance of PNAE and contributed to making the necessary adjustments to meet the program requirements, guided by its goals and guidelines.

At last, the study shows that interface between family farming and school feeding has being built in a collective movement to face challenges and difficulties, supported by dialogue, organization and intersectoral action of the social actors involved, as well as through investments performed by both parties. It shows that public policies as PNAE can provide favorable changes for farmers and the students and their communities, contributing to local development and for achieving higher levels of food security and nutrition both in rural as in urban spaces.

\section{References}

Alderman, H. \& Bundy, D. (2011) School Feeding Programs and Development: Are We Framing the Question Correctly? The World Bank Research Observer, Oxford, 27 (2): 204-221.

Ayres, J. R. C. M. et al. (2006). Vulnerability, Human Rights, and Comprehensive Health Care Needs of Young People Living With HIV/AIDS. American Journal of Public Health, New York, 96 (6): 1001-1006.

Baccarin, J. G. et al. (2011). Alimentação Escolar e agricultura familiar: alcance e dificuldades para implantação do Artigo 14 da Lei 11.947/2009 no Estado de São Paulo. In: Anais do 49o Congresso da Sober, 2011, Belo Horizonte. Anais... Belo Horizonte: Sober.

Baccarin, J. G. et al. (2012). Agricultura familiar e alimentação escolar sob a vigência da Lei 11.947/2009: adequação das chamadas públicas e disponibilidade de produtos no estado de São Paulo em 2011. In: 50 Congresso da Sociedade Brasileira de Economia,
Administração e Sociologia Rural, 2012, Vitória (ES). Anais... Vitória: SOBER, pp. 1-20. Disponível em: <http://icongresso.itarget.com.br/useradm/ anais/?clt=ser.2>. Acesso em 29 set. 2014.

Bavaresco, P. A. \& Mauro, F. (2012). Agricultura familiar brasileira no Programa Nacional de Alimentação Escolar: garantia de mercado aos agricultores e de segurança alimentar e nutricional aos alunos da rede pública de ensino. In: Fórum de Especialistas: Programas de Alimentação Escolar para América Latina e Caribe, 2012, Santiago. Anais... Santiago: FAO, pp. 1-7. Disponível em: <http://www.rlc.fao.org/fileadmin/ templates/fondobrasil/documentos/Foro_experto s/ Articulos/Artigo_Pedro_Bavaresco.pdf $>$. Acesso em: 29 set. 2014.

Bevilaqua, K. \& Triches, R. M. (2014). Implicações da venda de gêneros alimentícios ao Programa de Alimentação Escolar nos aspectos de renda e organização dos agricultores familiares. Segurança alimentar e nutricional, Campinas, v. 21, n. 2, p. 448-460.

Bezerra, O. M. P. A. et al. (2013). Promoção da aquisição de produtos da agricultura familiar para a alimentação escolar em Territórios da Cidadania de Minas Gerais e Espírito Santo. Revista de Nutrição, Campinas, v. 26, n. 3, p. 335-342.

Brasil (1955). Decreto n. 37.106, de 31 de março de 1955. Institui a Campanha da Merenda Escolar. Diário Oficial da União. Seção 1, p. 3.

Brasil (2009a). Fundo Nacional de Desenvolvimento da Educação (FNDE). Lei no 11.947, de 16 de junho de 2009. Dispõe sobre o atendimento da Alimentação escolar e do Programa Dinheiro Direto na Escola. Diário Oficial da União. Seção 1, p. 2.

Brasil (2010). Casa Civil. Lei no 12.188, de 11 de janeiro de 2010. Institui a Política Nacional de Assistência Técnica e Extensão Rural para a Agricultura Familiar e Reforma Agrária - PNATER e o Programa Nacional de Assistência Técnica e Extensão Rural na Agricultura Familiar e na Reforma Agrária - PRONATER, altera a Lei $\mathrm{n}^{\mathrm{o}}$ 8.666, de 21 de junho de 1993, e dá outras providências. Diário Oficial da União. Seção 1, p. 1.

Brasil (2003). Casa Civil. Lei no 10.696, de 2 de julho de 2003. Dispõe sobre a repactuação e o alongamento de dívidas oriundas de operações de crédito rural, e dá outras providências. Diário Oficial da União. Seção 1, p. 1.

Brasil (2013). Ministério da Educação. Fundo Nacional de Desenvolvimento da Educação - FNDE. Resolução no 26, de 17 de junho de 2013. Dispõe sobre o 
atendimento da alimentação escolar aos alunos da educação básica no âmbito do Programa Nacional de Alimentação Escolar - PNAE. Diário Oficial da União. Seção 1, p. 7.

Brasil (2016). Ministério da Educação. Fundo Nacional de Desenvolvimento da Educação - FNDE. Aquisição de produtos da agricultura familiar para a alimentação escolar. Ministério da Educação. Fundo Nacional de Desenvolvimento da Educação. 2. ed. Brasília: FNDE, 2016.

Bundy, D. et al. (2009). Rethinking school feeding: social safety nets, child development, and the education sector. Washington, DC: The World Bank.

Carney, D. (1999). Approaches to sustainable livelihoods for the rural poor. Overseas Development Institute Poverty Briefing, London, (2): 1-3.

Carvalho,D.G.de.(2009). Oprograma nacional dealimentação escolar e a sustentabilidade: o caso do Distrito Federal. 2009. 238 f. Dissertação (Mestrado em Desenvolvimento Sustentável) - Centro de Desenvolvimento Sustentável. Universidade de Brasília, Brasília.

Chaim, N. \& Belik, W. (2012). São Bernardo do Campo: atuação pioneira em favor da agricultura familiar. In Corá, M. A. J. \& Belik, W. (Orgs.). Ministério do Desenvolvimento agrário. Secretaria da Agricultura familiar. Projeto Nutre SP-análise da inclusão da agricultura familiar na alimentação escolar no estado de São Paulo. São Paulo: Instituto Via Pública.

Domene, S. M. A. (2008). A escola como ambiente de promoção da saúde e educação nutricional. Psicologia USP, São Paulo, 19 (4): 505-517.

FAO - Food and Agricultural Organization (2013). Alimentación escolar y las posibilidades de compra directa de la agricultura familiar: estudio de caso en ocho países. Santiago: FAO.

FAO - Food and Agricultural Organization (2014). Alimentar o mundo, cuidar do planeta. Montevideo: FAO.

Ellis, F. (2003a). A Livelihoods Approach to Migration and Poverty Reduction. Disponível em: $<$ http://citeseerx.ist. psu.edu/viewdoc/download?doi=10.1.1.553.5678\&rep $=$ rep1\&type $=$ pdf $>$. Acesso em: 22 jan. 2017.

Ellis, F. (2003b). Human Vulnerability and Food Insecurity: Policy Implications. Forum for Food Security in Southern Africa. Disponível em: <http://citeseerx. ist.psu.edu/viewdoc/summary?doi=10.1.1.524.9910>. Acesso em: 19 jan. 2017.

Ellis, F. et al. (2008). Social protection research scoping study. Disponível em: <http://www.gsdrc.org/docs/ open/hd542.pdf > . Acesso em: 08 jan. 2017.
Ellis, F. (2000). Determinants of livelihood diversification. In: Ellis, F. Rural Livelihoods and Diversity in Developing Countries. Oxford: Oxford University Press, pp. 55-80.

FNDE - Fundo Nacional do Desenvolvimento da Educação (2013). Dados da Agricultura Familiar. Disponível em: <http://www.fnde.gov.br/programas/ alimentacao-escolar/alimentacao-escolar-consultas/ dados-da-agricultura-familiar>. Acesso em: 15 jul. 2016.

Global Panel (2015). Healthy meals in schools: Policy Innovations Linking Agriculture, Food Systems and Nutrition. Policy Brief. London: Global Panel on Agriculture and Food Systems for Nutrition.

IBGE - Instituto Brasileiro de Geografia e Estatística (2002). Censo demográfico de 2000. Rio de Janeiro: IBGE. Disponível em: <http://www.ibge.gov.br/ home/estatistica/populacao/censo2000/populacao/ censo2000_populacao.pdf >. Acesso em: 20 mar. 2015.

IBGE - Instituto Brasileiro de Geografia e Estatística (2006). Censo Agropecuário 2006: Brasil, Grandes Regiões e Unidades da Federação. Censo agropecuário, Rio de Janeiro, pp. 1-777.

IBGE - Instituto Brasileiro de Geografia e Estatística (2011). Censo demográfico de 2010. Rio de Janeiro: IBGE. Disponível em: <http://www.brasileirosnomundo. itamaraty.gov.br/a-comunidade/estimativaspopulacionais-das-comunidades/estimativas-do-ibge/ censo-demografico-ibge-2010.pdf $>$. Acesso em: 20 mar. 2015.

Marcondes, T. (2010). Mudanças no espaço rural de Santa Catarina. In Vieira, L. M. Síntese Anual da Agricultura de Santa Catarina 2009-2010. Florianópolis: EPAGRI, pp. 12-24.

Marques, A. A. et al. (2014). Reflexões de agricultores familiares sobre a dinâmica de fornecimento de seus produtos para a alimentação escolar: o caso de Araripe, Ceará. Saúde e Sociedade, São Paulo, 23 (4): 1329-1341.

Mattei, L. (2010). Novo retrato da agricultura familiar em Santa Catarina. In: VIEIRA, Luiz Marcelino. Sintese Anual da Agricultura de Santa Catarina 2009-2010. Florianópolis: EPAGRI, pp. 25-35.

Minayo, M. C. S. (2013). O desafio do conhecimento: pesquisa qualitativa em saúde. 13. ed. São Paulo: HUCITEC.

Morgan, K. \& Sonnino, R. (2008). The school food revolution: public food and the challenge of sustainable devolopment. London: Earthscan. 
342 Interface Between Family Farming and School Feeding: barriers and coping mechanisms from the perspective of different social actors in Southern Brazil

Mosimann, E. N. (2014). Agricultura familiar e alimentação escolar nas encostas da serra geral de Santa Catarina: Desafios e potencialidades. 212f. Dissertação (Mestrado em Agroecossistemas) - Centro de Ciências Agrárias, Programa de Pós-graduação em Agroecossistemas. Universidade Federal de Santa Catarina, Florianópolis - SC.

Navarro, N. (2011). A intersetorialidade como modelo de gestão das políticas de combate à pobreza no Brasil: o caso do programa Bolsa Família no município de Guarulhos. 166 f. Dissertação (Mestrado em Administração Pública e Governo) - Escola de Administração de Empresas de São Paulo. Fundação Getulio Vargas, São Paulo.

Nunes, A. R. (2016). Assets for health: linking vulnerability, resilience and adaptation to climate change. Disponível em: < < <ttp://www.tyndall.ac.uk/publications/ tyndall-working-paper/2016/assets-health-linkingvulnerability-resilience-and-adaptatio $>$. Acesso em: 28 dez. 2016.

Oliveira, T. R. P. R., Sousa, H. C. \& Silva, A. P. (2013). Agricultura familiar na alimentação escolar: estudo de caso em dois municípios de Minas Gerais. Nutrire: Revista da Sociedade Brasileira de Alimentação e Nutrição, São Paulo, 38 (3): 256-268.

Peixinho, A. M. L. (2013). A trajetória do Programa Nacional de Alimentação Escolar no período de 20032010: relato do gestor nacional. Ciência e Saúde Coletiva, Rio de Janeiro, 18 (4): 909-916.

Reinach, S., Corá, M. A. J. \& Bonduki, M. R. P. C. (2012). A Inclusão da Agricultura Familiar no Programa Nacional de Alimentação Escolar. In: XXXVI ENCONTRO DA AMPAD, 2012, Rio de Janeiro, Anais... Rio de Janeiro: ANPAD, pp. 1-15. Disponível em: < http://www.anpad. org.br/admin/pdf/2012_APB2404.pdf $>$. Acesso em 28 jul. 2015.

Rocha, C. (2009). Developments in national policies for food and nutrition security in Brazil. Development Policy Review, Oxford, 27 (1): 51-66.

Saraiva, E. B. et al. (2013). Panorama da compra de alimentos da agricultura familiar para o Programa Nacional de Alimentação Escolar. Ciência e Saúde Coletiva, Rio de Janeiro, 18 (4): 927-935.

Silva, D. B. P.et al. (2013). Os agentes sociais e o Programa Nacional de Alimentação Escolar (PNAE): a percepção dos agricultores familiares. In: Encontro Internacional Participação, Democracia e Políticas Públicas: Aproximando Agendas e Agentes, 2013, Araraquara. Anais... Araraquara: UNESP, pp. 1-18. Disponível em: <http://www.encontropdpp.sinteseeventos.com.br/>. Acesso em: 15 out. 2014.

Silva, M. G., Dias, M. M. \& Junior, P. C. G. A. (2015). Mudanças organizacionais em empreendimentos de agricultura familiar a partir do acesso ao Programa Nacional de Alimentação Escolar. Revista de Economia e Sociologia Rural, Piracicaba, 53 (2): 289-304.

Soares, P. et al. (2015). Potencialidades e dificuldades para o abastecimento da alimentação escolar mediante a aquisição de alimentos da agricultura familiar em um município brasileiro. Ciência e Saúde Coletiva, Rio de Janeiro, 20 (6): 1891-1900.

Sousa, L. M. et al. (2013). Alimentação escolar nas comunidades quilombolas: desafios e potencialidades. Ciência e Saúde Coletiva, Rio de Janeiro, 18 (4): 987-992.

Souza, L. B. B. (2012). Organizações da agricultura familiar no Estado de São Paulo e sua experiência de fornecimento para o PNAE. In Souza, L. B. B. Projeto Nutre SP-análise da inclusão da agricultura familiar na alimentação escolar no estado de São Paulo. São Paulo: Instituto Via Pública.

Spinelli, M A. S. \& Canesqui, A. M. (2002). O programa de alimentação escolar no estado de Mato Grosso: da centralização à descentralização (1979-1995). Revista de Nutrição, Campinas, 15 (1): 105-117.

Triches R. M. \& Schneider, S. (2010). Alimentação escolar e agricultura familiar: reconectando o consumo à produção. Saúde e Sociedade, São Paulo, 19 (4): 933-945.

Triches, R. M. \& Baccarin, J. G. (2016). Interações entre alimentação escolar e agricultura familiar para o desenvolvimento local. In Teo, C. R. P. A. \& Triches, R. M. (Orgs.). Alimentação escolar - construindo interfaces entre saúde, educação e desenvolvimento. Chapecó (SC): Argos, pp. 89-110.

Triches, R. M., Gerhardt, T. E. \& Schneider, S. (2014). Políticas alimentares: interações entre saúde, consumo e produção de alimentos. Interações, Campo Grande, 15 (1): 109-120.

Triches, R. M. \& Schneider, S. (2012). Desestruturar para construir: interfaces para agricultura familiar acessar o Programa de Alimentação Escolar. Revista Estudos Sociedade e Agricultura (UFRJ), Rio de Janeiro, 20 (1): 66-106.

Zoldan, P. (2010). O PIB e a evolução recente da economia catarinense. In Vieira, L. M. Sintese Anual da Agricultura de Santa Catarina 2009-2010. Florianópolis: EPAGRI, pp. 7-11. 